J URARARASI TEKIIK SIPIL 


\section{JURNAL GRADASI TEKNIK SIPIL POLITEKNIK NEGERI BANJARMASIN}

Jurnal Gradasi Teknik Sipil diterbitkan oleh Pusat Penelitian dan Pengabdian Kepada Masyarakat Politeknik Negeri Banjarmasin. Ruang lingkup makalah meliputi Bidang Teknik dan Manajemen dengan konsentrasi Bidang Transportasi, Geoteknik, Struktur, Keairan dan Manajemen Konstruksi. Isi makalah dapat berupa penyajian isu aktual di bidang Teknik Sipil, review terhadap perkembangan penelitian, pemaparan hasil penelitian, dan pengembangan metode, aplikasi, dan prosedur di bidang Teknik Sipil. Makalah ditulis mengikuti panduan penulisan.

\section{Penanggung Jawab}

Nurmahaludin, ST, MT.

\section{Dewan Redaksi}

Ketua $\quad$ : $\quad$ Dr. Fitriani Hayati, ST, M.Si.

Anggota $\quad$ : $\quad$ Riska Hawinuti, ST, MT.

Nurfitriah, S.Pd, MA.

Ir. Rusliansyah, M.Sc.

\section{Reviewer}

Dr. Ir. Yanuar Jarwadi Purwanto, MS. (Institut Pertanian Bogor)

Dr. Ir. Achmad Rusdiansyah, MT. (Universitas Lambung Mangkurat)

Dr. Ir. M. Azhar, M. Sc. (Institut Sains dan Teknologi Nasional)

Dr. Ir. Endang Widjajanti, MT. (Institut Sains dan Teknologi Nasional)

Joni Irawan, ST, MT. (Politeknik Negeri Banjarmasin)

Yusti Yudiawati, ST, MT. (Politeknik Negeri Banjarmasin)

\section{Editing dan Tata Bahasa}

Nurfitriah, S.Pd., MA.

\section{Desain dan Tata Letak}

Abdul Hafizh Ihsani

\section{Alamat Redaksi}

Jurusan Gradasi Teknik Sipil Politeknik Negeri Banjarmasin, Jl. Brigjen H. Hasan Basri 70123 Banjarmasin Telp/Fax 0511-3307757; Email: gradasi.tekniksipil@poliban.ac.id 


\section{JURNAL GRADASI TEKNIK SIPIL}

\section{DAFTAR ISI}

Perencanaan Struktur Atas Jembatan Komposit Sungai Nipah Desa Darul Aman Kecamatan Rupat ...( 1 - 9 )

Nur Aspaliza, Indriyani Puluhulawa, Armada

Perencanaan Jembatan Rangka Baja Pelengkung Sungai Liong ...( 10 - 21 )

Febry Suhendra, Faisal Ananda, Alamsyah

Pengaruh Agregat Setempat Terhadap Nilai Indeks dan Biaya pada Analisa Satuan

Pekerjaan Beton f'c $20 \mathrm{MPa}$... ( 22 - 29 )

Muhammad Humaidi, Khairil Yanuar, Aunur Rafik

Pengaruh Posisi, Jumlah Layer Dan Mutu Kayu Terhadap Balok Laminasi Kayu Mahang Dan Kayu Meranti ...( 30 - 35 )

Indriyani Puluhulawa

Pengaruh Supeltas Terhadap Tingkat Pelayanan Simpang Jalan Trans KalimantanKomplek Griya Permata ...( $36-44)$

Riska Hawinuti

Perancangan Lapis Pondasi Agregat Tanpa Penutup Aspal Gradasi Batas Tengah Menggunakan Claystone ...( 45 - 54 )

Ahmad Norhadi, H. Muhammad Fauzi, Akhmad Marzuki, Zuraida 


\title{
Perencanaan Jembatan Rangka Baja Pelengkung Sungai Liong
}

\author{
Febry Suhendra ${ }^{1 *}$, Faisal Ananda ${ }^{2}$, Alamsyah $^{3}$ \\ ${ }^{1}$ Mahasiswa Jurusan Teknik Sipil Politeknik Negeri Bengkalis \\ ${ }^{2,3}$ Mahasiswa Jurusan Teknik Sipil Politeknik Negeri Bengkalis \\ e-mail:*1febrysuhendra1996@gmail.com (corresponding author), 2 faisalananda@polbeng.ac.id, \\ 3alamsyah@polbeng.ac.id
}

\begin{abstract}
Abstrak
Pemerintah Bengkalis melaksanakan pembangunan jembatan sungai Liong dengan tipe konstruksi jembatan rangka pelengkung beton. Namun pada masa layan yang relatif baru, terjadi lendutan yang sangat besar disalah satu segmen jembatan. Dalam penelitian ini dilakukan perencanaan jembatan tipe rangka pelengkung baja.

Perencanaan jembatan menggunakan RSNI T-02-2005 tentang standart pembebanan jembatan. Untuk desain rangka baja mengacu kepada RSNI T-03-2005 sedangkan desain struktur beton mengacu kepada RSNI T-122004. Dalam perhitungan kebutuhan tiang pancang, menggunakan metode Schmertmann.

Hasil perhitungan struktur atas jembatan didapati profil yang aman digunakan untuk struktur rangka baja yaitu Pelengkung atas menggunakan WF.305.305.22.35, Pelengkung bawah profil WF. 305.305.39.63, Profil diagonal WF.305.305.22.35, Batang tarik vertikal WF 203.203.10.17, Ikatan angin rangka profil WF.203.203.8.12, Pengaku rangka profil 203.203.8.12, Gelagar memanjang profil WF.400.200.8.13, Gelagar melintang profil WF.500.200.10.16, serta Gelagar utama memanjang menggunakan profil WF.500.200.10.16. Hasil perhitungan struktur bawah jembatan didapati lebar tapak abutment 9,3 $\mathrm{m}$ dengan panjang abutment $11 \mathrm{~m}$. Digunakan tiang pancang beton berdiameter $50 \mathrm{~cm}$ dengan panjang $20 \mathrm{~m}$ dan terdapat 28 titik pemancangan. Lendutan terbesar jembatan yaitu 118,72 mm. Lendutan ini masih dikategorikan aman karena nilainya lebih kecil dari lendutan ijin L/240 sebesar 458,33 mm. Adapun metode pelaksanaan yang paling tepat untuk pembangunan jembatan Sungai Liong II ini adalah metode Temporary Coloumns.
\end{abstract}

Kata kunci-Jembatan Pelengkung Baja, Lendutan, Sungai Liong

\section{Abstract}

Bengkalis government do project to build Liong river bridge with construction type is concrete arch bridge. But at relatively new service time, there was a big deflection in one of bridge segments. In this research will be design the bridge with steel arch bridge type.

Bridge design using RSNI T-02-2005 about bridge load standard. For steel frame design refers to RSNI T-03-2005, and concrete structure design refers to RSNI T-12-2004. In piles calculation, using the Schmertmann method.

The results of top structure design is top chord using WF.305.305.22.35, bottom chord WF. 305.305.39.63, diagonal chord WF.305.305.22.35, vertical hanger WF 203.203.10.17, wind bracing WF.203.203.8.12, truss bracing WF.203.203.8.12, girder using WF.400.200.8.13, cross girder WF.500.200.10.16, and the main girder using WF.500.200.10.16 profile. The results of bottom structure design is abutment width of $9,3 \mathrm{~m}$ and abutment length of $11 \mathrm{~m}$. Using concrete piles with diameter of $50 \mathrm{~cm}$, length $20 \mathrm{~m}$ and 28 point of stake. The largest deflection of bridge is $118,72 \mathrm{~mm}$. This deflection is still safe because the value smaller than tolerance deflection L/240, which is $458,33 \mathrm{~mm}$. The most compatible construction method for liong II river bridge is temporary coloumn method.

Keywords - Steel Arch Bridge, Deflection, Liong River 


\section{PENDAHULUAN}

Sungai Liong merupakan salah satu sungai besar yang ada di pulau Bengkalis tepatnya di kecamatan Bantan. Pemerintah Kabupaten Bengkalis melalui Dinas Pekerjaan Umum dan Penataan Ruang melaksanakan realisasi pembangunan jembatan sungai Liong dengan tipe konstruksi jembatan rangka pelengkung beton. Namun pada masa layan yang relatif masih baru, terjadi lendutan yang sangat besar disalah satu segmen jembatan. Perkiraan awal penyebab terjadinya lendutan pada salah satu segmen jembatan yaitu akibat beban rangka pelengkung yang terbuat dari beton.

Rangka pelengkung pada jembatan memiliki fungsi untuk menahan gaya tekan akibat beban yang terjadi dan batang penyalurnya akan mengalami gaya tarik. Umumnya profil dengan material baja akan menahan gaya tekan dan tarik akibat beban dengan lebih baik.

Batang penyalur yang terbuat dari beton tidak akan berkonstribusi banyak menahan gaya tarik, bahkan menjadi beban bagi gelagar dan rangka pelengkung jembatan. Penggunaan material baja akan lebih efektif dengan penampang yang lebih kecil namun memiliki tahanan yang lebih besar menjadikan bobot jembatan dapat lebih ringan. Untuk itu dalam penelitian ini akan coba dilakukan perencanaan jembatan rangka baja pelengkung dengan studi kasus jembatan sungai Liong.

Adapun tujuan perencanaan ini yaitu untuk mendapatkan hasil perencanaan struktur atas dan bawah jembatan serta mendapatkan lendutan total jembatan akibat pembebanan jika konstruksi jembatan menggunakan tipe rangka pelengkung profil baja.

\section{METODE PENELITIAN}

Adapun tahapan perencanaan yang dilakukan sebagai berikut:

1) Pengumpulan data-data yang diperlukan guna menunjang dalam perencanaan jembatan. Yaitu data tipe jembatan, topografi, hidrologi dan data sondir. Metode pengumpulan data yaitu dengan literatur data milik Dinas Pekerjaan Umum Kabupaten Bengkalis. Namun apabila terdapat data yang masih kurang akan dilakukan pengumpulan dengan metode observasi survey dilapangan.

2) Preliminery Design, melakukan perencanaan desain awal berupa asumsi-asumsi yang dapat digunakan, akan tetapi bila setelah dicek kestabilan, kekokohan, keamanan, kelayakan dan kenyamanan konstruksi tidak memenuhi maka desain harus diubah.

3) Perhitungan pembebanan mengacu kepada RSNI T-02-2005.

4) Desain kekuatan profil rangka baja mengacu kepada RSNI T-03-2005. Meliputi perencanaan gelagar memanjang, gelagar melintang, ikatan angin dan rangka pelengkung jembatan.

5) Desain elemen struktur beton pada jembatan mengacu kepada RSNI T-12-2004. Meliputi desain slab, trotoar dan railing.

6) Perhitungan analisis struktur gaya dalam menggunakan program bantu Structural Analysis Program (SAP) 2000.

7) Desain penulangan pelat lantai kendaraan.

8) Perencanaan dimensi balok gelagar memanjang, gelagar melintang jembatan dan stud connector. Serta plat bondex yang akan menjadi perancah pada saat pengecoran pelat lantai pada saat pembangunan.

9) Perhitungan profil baja untuk rangka pelengkung jembatan. Rangka pelengkung didesain menggunakan profil Wide Flange (WF) dengan dimensi dan ketebalan berdasarkan besaran gaya aksial yang terjadi.

10) Kemudian dilakukan perencanaan batang tarik vertikal yang menggunakan profil Wide Flange (WF) berdasarkan gaya aksial tarik yang terjadi.

11) Dilanjutkan dengan perhitungan sambungan baut pada joint yang paling menentukan.

12) Perencanaan perletakan berupa elastomer bearing.

13) Perencanaan abutment jembatan, meliputi desain backwall, breastwall, pilecap dan pemancangan spun pile.

14) Pengecekan keamanan pondasi jembatan terhadap safety factor, PU Max dan penurunan. 
15) Setelah seluruh dimensi dan penulangan jembatan didapati, dilanjutkan dengan pembuatan gambar rencana jembatan.

\section{III.HASIL DAN PEMBAHASAN}

\section{A. Data Teknis Jembatan}

Adapun data teknis jembatan Sungai Liong II meliputi:
1) Jumlah Bentang
2) Panjang Bentang
3) Lebar Jalur Lalu Lintas
4) Lebar Trotoar
5) Lebar Total Jembatan
6) Lebar Total Rangka Jembatan
7) Tebal Slab Jembatan
$\begin{array}{rr}= & 1 \\ = & 110 \mathrm{~m} \\ = & 6 \mathrm{~m}\end{array}$
$=\quad 6 \mathrm{~m}$
$=\quad 0,5 \mathrm{~m}$
$\begin{array}{rr}= & 0,5 \mathrm{~m} \\ = & 7 \mathrm{~m}\end{array}$
$=\quad 9,1 \mathrm{~m}$
$=0,25 \mathrm{~m}$
8) Tebal lapisan Aspal + Overlay
$=0,1 \mathrm{~m}$
9) Tebal Genangan Air Hujan
$=0,05 \mathrm{~m}$
10) Jarak Antar Batang Tarik Vertikal =
$5 \mathrm{~m}$
11) Jarak Antar Balok Memanjang $=1,7 \mathrm{~m}$

Kemudian mutu beton yang digunakan adalah sebagai berikut:
1) Mutu Beton
2) Kuat Tekan Beton
K - 300
3) Modulus Elastis Beton
$=25,38 \mathrm{MPa}$
4) Angka Poison Beton
$\mathrm{Ec}=23679 \mathrm{MPa}$
5) Koef. Muai Panjang Beton
$v=0,2$
$\alpha=1 \times 10-5 /{ }^{0} \mathrm{C}$

Mutu baja yang digunakan adalah sebagai berikut:
1) Mutu Baja Profil
Tegangan Leleh
Tegangan Putus
U - 41
$\mathrm{Fy}=410 \mathrm{MPa}$
$\mathrm{Fu}=550 \mathrm{MPa}$
2) Baja Tulangan $\varnothing>12 \mathrm{~mm}$
U - $\quad 39$
Tegangan Leleh
$\mathrm{Fy}=390 \mathrm{MPa}$
3) Baja Tulangan $\varnothing \leq 12 \mathrm{~mm}$
$\mathrm{U}-24$
4) Tegangan Leleh
$\mathrm{Fy}=240 \mathrm{MPa}$

\section{B. Pembebanan}

1) Berat Sendiri (MS)

Beban trotoar $\quad \mathrm{Wtr}=6 \mathrm{kN} / \mathrm{m}^{2}$

2) Beban Mati Tambahan (MA)

Berat aspal + overlay

Berat genangan air hujan

$\mathrm{Wa}=2,2 \mathrm{kN} / \mathrm{m}^{2}$

Berat tiang listrik

3) Beban Lajur "D" (TD)

\section{Beban UDL}

Beban KEL

4) Gaya Rem (TB)

Gaya Rem

Jumlah joint

Gaya rem tiap joint

5) Beban Pejalan Kaki (TP)

Intensitas beban trotoar $\quad \mathrm{Q}_{\mathrm{TP}}=2 \mathrm{kN} / \mathrm{m}^{2}$

6) Pengaruh Temperatur (ET)

Temperatur maksimum $\quad \mathrm{T}_{\max }=40{ }^{\circ} \mathrm{C}$

Temperatur minimum $\quad \mathrm{T}_{\min }=25^{\circ} \mathrm{C}$

Selisih Temperatur $\quad \Delta \mathrm{T}=15^{\circ} \mathrm{C}$

7) Beban Angin (EW)

Beban angin

Jumlah joint

Beban angin tiap joint

$\mathrm{T}_{\mathrm{EW}}=611 \mathrm{kN}$

$\mathrm{n}=67$ joint

8) Beban Gempa (EQ)

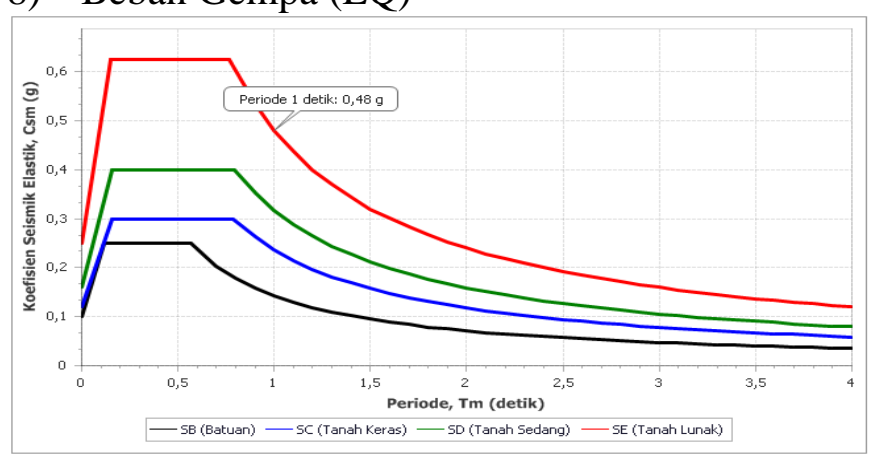

Gambar 1. Grafik Respon Spektrum Gempa

9) Kombinasi Gempa

Tabel I

Kombinasi Beban Ultimit

\begin{tabular}{|l|c|c|c|c|c|}
\hline \multirow{2}{*}{ Aksi / Beban } & \multirow{2}{*}{$\begin{array}{c}\text { Faktor } \\
\text { Beban }\end{array}$} & \multicolumn{5}{|c|}{ Kombinasi } \\
\cline { 3 - 6 } & & 1 & 2 & 3 & 4 \\
\hline Aksi Tetap & & & & & \\
\hline MS & $\mathrm{K}_{\mathrm{MS}}$ & 1,30 & 1,30 & 1,30 & 1,30 \\
\hline MA & $\mathrm{K}_{\mathrm{MA}}$ & 2,00 & 2,00 & 2,00 & 2,00 \\
\hline Aksi Transien & & & & & \\
\hline TD & $\mathrm{K}_{\mathrm{TD}}$ & 2,00 & 1,00 & 1,00 & \\
\hline TB & $\mathrm{K}_{\mathrm{TB}}$ & 2,00 & 1,00 & 1,00 & \\
\hline TP & $\mathrm{K}_{\mathrm{TP}}$ & & 2,00 & & \\
\hline Aksi Lingkungan & & & & & \\
\hline ET & $\mathrm{K}_{\mathrm{ET}}$ & 1,00 & 1,20 & 1,20 & \\
\hline EW & $\mathrm{K}_{\mathrm{EW}}$ & 1,00 & & 1,20 & \\
\hline
\end{tabular}




\begin{tabular}{|l|l|l|l|l|l|}
\hline EQ & $\mathrm{K}_{\mathrm{EQ}}$ & & & & 1,00 \\
\hline
\end{tabular}

Tabel II

Kombinasi Beban Kerja

\begin{tabular}{|l|c|c|c|c|c|}
\hline \multirow{2}{*}{ Aksi / Beban } & \multirow{2}{*}{$\begin{array}{c}\text { Faktor } \\
\text { Beban }\end{array}$} & \multicolumn{5}{|c|}{ Kombinasi } \\
\cline { 3 - 6 } & & 1 & 2 & 3 & 4 \\
\hline Aksi Tetap & & & & & \\
\hline MS & $\mathrm{K}_{\mathrm{MS}}$ & 1,00 & 1,00 & 1,00 & 1,00 \\
\hline MA & $\mathrm{K}_{\mathrm{MA}}$ & 1,00 & 1,00 & 1,00 & 1,00 \\
\hline Aksi Transien & & & & & \\
\hline TD & $\mathrm{K}_{\mathrm{TD}}$ & 1,00 & 1,00 & 1,00 & \\
\hline $\mathrm{TB}$ & $\mathrm{K}_{\mathrm{TB}}$ & 1,00 & 1,00 & 1,00 & \\
\hline TP & $\mathrm{K}_{\mathrm{TP}}$ & & 1,00 & 1,00 & \\
\hline Aksi Lingkungan & & & & & \\
\hline ET & $\mathrm{K}_{\mathrm{ET}}$ & & 1,00 & 1,00 & \\
\hline EW & $\mathrm{K}_{\mathrm{EW}}$ & & & 1,00 & \\
\hline EQ & $\mathrm{K}_{\mathrm{EQ}}$ & & & & 1,00 \\
\hline Kelebihan Tegangan & & $0 \%$ & $25 \%$ & $40 \%$ & $50 \%$ \\
\hline
\end{tabular}

10) Analisis beban menggunakan SAP 2000

Agar penentuan ukuran profil menjadi lebih mudah dan cepat, digunakan fungsi auto select pada frame section. Sehingga nantinya program bantu SAP 2000 yang akan memilih profil yang paling tepat sesuai dengan gaya aksial dan momen yang terjadi.

Hasil analisis SAP 2000 didapati profil sebagai berikut:
a. Pelengkung atas
WF.305.305.22.35
b. Pelengkung bawah 1
WF.305.305.39.63
c. Pelengkung bawah 2
WF.305.305.22.35
d. Diagonal truss
WF.305.305.22.35
e. Batang tarik vertikal
WF.203.203.8.12
f. Ikatan angin rangka
WF.203.203.8.12
g. Pengaku rangka
h. Gelagar memanjang
WF.203.203.8.12
WF.400.200.8.13
i. Gelagar melintang
WF.500.200.10.16
j. Gelagar utama memanjang WF.500.200.10.16
k. Ikatan Angin Gelagar
WF.203.203.8.12

Tahanan momen profil:

$\begin{array}{lll}\mathrm{Mn} & = & \mathrm{fy} * \mathrm{Zx} \\ \mathrm{Mn} & = & 410 \times 1190 \times 10^{3} \\ \mathrm{Mn} & = & 487900000 \mathrm{Nmm} \\ \mathrm{Mn} & = & 487,9 \mathrm{kNm}\end{array}$

Cek Kekuatan:

$\mathrm{Mu} \leq \varnothing \mathrm{Mn}$

$\mathrm{Mu} \quad=\quad 209,427 \mathrm{kNm}$

$\varnothing \mathrm{Mn}=0,9 * 487,9$

$\varnothing \mathrm{Mn} \quad=\quad 439,11 \mathrm{kNm}$

Rasio Kekuatan:

$\mathrm{Mu} / \varnothing \mathrm{Mn}=209,43 / 439,11=0,48$

Tahanan geser profil:

$\begin{array}{lll}\mathrm{Vn} & = & 0,6 * \mathrm{fy} *(\mathrm{H} * \mathrm{tw}) \\ \mathrm{Vn} & = & 0,6 * 410 *(400 * 8) \\ \mathrm{Vn} & = & 787,20 \mathrm{kN} \\ \varnothing \mathrm{Vn} & = & 0,9 * 787,20 \\ \varnothing \mathrm{Vn} & = & 708,48 \mathrm{kN}\end{array}$

Cek kekuatan geser:

$\mathrm{Vu} \leq \varnothing \mathrm{Vn}$

$\mathrm{Vu} \quad=\quad 86,649 \mathrm{kN}$

Rasio kekuatan nilainya lebih kecil dari 1 , maka profil WF.400.200.8.13 aman digunakan.

2) Gelagar Melintang

Tahanan momen profil:

$\mathrm{Mn} \quad=\quad$ fy $* \mathrm{Zx}$

$\mathrm{Mn} \quad=\quad 410 \times 1910 \times 103$

$\mathrm{Mn} \quad=\quad 783100000 \mathrm{Nmm}$

$\mathrm{Mn} \quad=\quad 783,1 \mathrm{kNm}$

Cek Kekuatan:

$\mathrm{Mu} \leq \varnothing \mathrm{Mn}$

$\mathrm{Mu} \quad=\quad 364,03 \mathrm{kNm}$

$\varnothing \mathrm{Mn}=0,9 * 783,1$

$\varnothing \mathrm{Mn} \quad=\quad 704,79 \mathrm{kNm}$

Rasio Kekuatan:

$\mathrm{Mu} / \varnothing \mathrm{Mn}=364,03 / 704,79=0,52$

Tahanan geser profil:

$\begin{array}{lll}\mathrm{Vn} & = & 0,6 * \mathrm{fy} *(\mathrm{H} * \mathrm{tw}) \\ \mathrm{Vn} & = & 0,6 * 410 *(500 * 10) \\ \mathrm{Vn} & = & 1230 \mathrm{kN} \\ \varnothing \mathrm{Vn} & = & 0,9 * 1230 \\ \varnothing \mathrm{Vn} & = & 1107 \mathrm{kN}\end{array}$

Cek kekuatan geser:

$\mathrm{Vu} \leq \varnothing \mathrm{Vn}$

$\mathrm{Vu} \quad=\quad 769,126 \mathrm{kN}$ 
Rasio kekuatan nilainya lebih kecil dari 1, maka profil WF.500.200.10.16 aman digunakan.

3) Gelagar Utama Memanjang

Tahanan momen profil:

$\begin{array}{lll}\mathrm{Mn} & = & \mathrm{fy} * \mathrm{Zx} \\ \mathrm{Mn} & = & 410 \times 1910 \times 103 \\ \mathrm{Mn} & = & 783100000 \mathrm{Nmm} \\ \mathrm{Mn} & = & 783,1 \mathrm{kNm}\end{array}$

Cek Kekuatan:

$\mathrm{Mu} \leq \varnothing \mathrm{Mn}$

$\mathrm{Mu} \quad=\quad 364,03 \mathrm{kNm}$

$\varnothing \mathrm{Mn}=0,9 * 783,1$

$\varnothing \mathrm{Mn} \quad=\quad 704,79 \mathrm{kNm}$

Rasio Kekuatan:

$\mathrm{Mu} / \varnothing \mathrm{Mn}=365,07 / 704,79=0,52$

Tahanan geser profil:
$\mathrm{Vn}=0,6 *$ fy $*(\mathrm{H} * \mathrm{tw})$
$\mathrm{Vn}=0,6 * 410 *(500 * 10)$
$\mathrm{Vn} \quad=1230 \mathrm{kN}$
$\varnothing \mathrm{Vn}=0,9 * 1230$
$\varnothing \mathrm{Vn}=1107 \mathrm{kN}$

Cek kekuatan geser:

$\mathrm{Vu} \leq \varnothing \mathrm{Vn}$

$\mathrm{Vu} \quad=\quad 147,877 \mathrm{kN}$

Rasio kekuatan nilainya lebih kecil dari 1, maka profil WF.500.200.10.16 aman digunakan.

D. Perencanaan Struktur Rangka Jembatan

1) Profil Pelengkung 1 (Aksial Tekan)

$\lambda c=\frac{L * k}{i \min * \pi} \sqrt{\frac{f y}{E}}=1,06$

$\lambda c<1,5$ maka,

$\omega=\frac{1}{0,66^{\lambda c^{2}}}=1,59$

$\mathrm{Nn}=\frac{\text { Ag*fy }}{\omega}=13636,4 \mathrm{kN}$

$\varnothing \mathrm{Nn}=0,85 * 13636,4=11590,92 \mathrm{kN}$

Rasio Kekuatan:

$\frac{\mathrm{Nu}}{\emptyset \mathrm{Nn}}=\frac{8313,5}{11590,92}=0,72$

Rasio kekuatan nilainya lebih kecil dari 1, maka profil WF.305.305.39.63 aman digunakan.

2) Profil Pelengkung 2 (Aksial Tekan) $\lambda c=\frac{L * k}{i \min * \pi} \sqrt{\frac{f y}{E}}=1,01$

$\lambda \mathrm{c}<1,5$ maka,

$\omega=\frac{1}{0,66^{\lambda c^{2}}}=1,53$

$\mathrm{Nn}=\frac{\text { Ag*fy }}{\omega}=7717,3 \mathrm{kN}$

$\varnothing \mathrm{Nn}=0,85 * 8426,7=6559,69 \mathrm{kN}$

Rasio Kekuatan:

$\frac{\mathrm{Nu}}{\emptyset \mathrm{Nn}}=\frac{5435,75}{6559,69}=0,83$

Rasio kekuatan nilainya lebih kecil dari 1, maka profil WF.305.305.22.35 aman digunakan.

3) Profil Diagonal (Aksial Tarik)

$$
\begin{aligned}
& \mathrm{Pu} \leq \varnothing \mathrm{Pn} \\
& \mathrm{Pn}=\mathrm{Ag} * \mathrm{fy} \\
& \mathrm{Pn}=11824,4 \mathrm{kN} \\
& \varnothing \mathrm{Pn}=0,75 * 11824,4=10641,96 \mathrm{kN}
\end{aligned}
$$

Rasio Kekuatan:

$\frac{\mathrm{Pu}}{\emptyset \mathrm{Pn}}=\frac{906}{10641,96}=0,09$

Rasio kekuatan nilainya lebih kecil dari 1, maka profil WF.305.305.22.35 aman terhadap kelelehan.

$$
\begin{aligned}
& \mathrm{Pu} \leq \varnothing \mathrm{Pn} \\
& \mathrm{Pn}=\mathrm{Ae} * \mathrm{fu} \\
& \mathrm{Pn}=(\mathrm{Ag} * \mathrm{U}) * \mathrm{fu} \\
& \mathrm{Pn}=13482,7 \mathrm{kN} \\
& \varnothing \mathrm{Pn}=0,75 * 13482,7=10112,03 \mathrm{kN}
\end{aligned}
$$

Rasio Kekuatan:

$$
\frac{\mathrm{Pu}}{\emptyset \mathrm{Pn}}=0,09
$$

Rasio kekuatan nilainya lebih kecil dari 1, maka profil WF.305.305.22.35 aman terhadap fraktur.

4) Batang Tarik Vertikal (Aksial Tarik)

$$
\begin{aligned}
& \mathrm{Pu} \leq \varnothing \mathrm{Pn} \\
& \mathrm{Pn}=\mathrm{Ag} * \mathrm{fy} \\
& \mathrm{Pn}=2724,45 \mathrm{kN} \\
& \varnothing \mathrm{Pn}=0,75 * 2724,45=2452,01 \mathrm{kN}
\end{aligned}
$$


Rasio Kekuatan:
$\frac{\mathrm{Pu}}{\emptyset \mathrm{Pn}}=\frac{723,36}{2452,01}=0,30$

Rasio kekuatan nilainya lebih kecil dari 1, maka profil WF.203.203.8.12 aman terhadap kelelehan.

$$
\begin{aligned}
& \mathrm{Pu} \leq \varnothing \mathrm{Pn} \\
& \mathrm{Pn}=\mathrm{Ae} * \mathrm{fu} \\
& \mathrm{Pn}=(\mathrm{Ag} * \mathrm{U}) * \mathrm{fu} \\
& \mathrm{Pn}=3106,54 \mathrm{kN} \\
& \varnothing \mathrm{Pn}=0,75 * 3106,54=2329,9 \mathrm{kN}
\end{aligned}
$$

Rasio Kekuatan:

$$
\frac{\mathrm{Pu}}{\emptyset \mathrm{Pn}}=\frac{723,36}{2329,9}=0,31
$$

Rasio kekuatan nilainya lebih kecil dari 1, maka profil WF.203.203.8.12 aman terhadap fraktur.

5) Ikatan Angin Rangka (Aksial Tarik)

$$
\begin{aligned}
& \mathrm{Pu} \leq \varnothing \mathrm{Pn} \\
& \mathrm{Pn}=\mathrm{Ag} * \text { fy } \\
& \mathrm{Pn}=2724,45 \mathrm{kN} \\
& \varnothing \mathrm{Pn}=0,75 * 2724,45= \\
& \mathrm{Rasio} \text { Kekuatan: } \\
& \frac{\mathrm{Pu}}{\emptyset \mathrm{Pn}}=\frac{74,6}{2452,01}=0,03
\end{aligned}
$$$$
\varnothing \mathrm{Pn}=0,75 * 2724,45=2452,01 \mathrm{kN}
$$

Rasio kekuatan nilainya lebih kecil dari 1, maka profil WF.203.203.8.12 aman terhadap kelelehan.

$$
\begin{aligned}
& \mathrm{Pu} \leq \varnothing \mathrm{Pn} \\
& \mathrm{Pn}=\mathrm{Ae} * \mathrm{fu} \\
& \mathrm{Pn}=(\mathrm{Ag} * \mathrm{U}) * \mathrm{fu} \\
& \mathrm{Pn}=3106,54 \mathrm{kN} \\
& \varnothing \mathrm{Pn}=0,75 * 3106,54=2329,9 \mathrm{kN}
\end{aligned}
$$

Rasio Kekuatan:

$$
\frac{\mathrm{Pu}}{\emptyset \mathrm{Pn}}=\frac{74,6}{2329,9}=0,03
$$

Rasio kekuatan nilainya lebih kecil dari 1, maka profil WF.203.203.8.12 aman terhadap fraktur.

6) Ikatan Angin Rangka (Aksial Tekan)

$$
\begin{aligned}
\lambda \mathrm{c} & =\frac{L * k}{i \min * \pi} \sqrt{\frac{f y}{E}}=1,75 \\
\lambda \mathrm{c} & >1,5 \text { maka, }
\end{aligned}
$$

$$
\mathrm{Nn}=\frac{0,88 * \mathrm{Ag} * \mathrm{fy}}{\lambda \mathrm{c}^{2}}=782,5 \mathrm{kN}
$$

$\varnothing \mathrm{Nn}=0,85 * 782,5=665,15 \mathrm{kN}$

Rasio Kekuatan:

$\frac{\mathrm{Nu}}{\emptyset \mathrm{Nn}}=\frac{61,48}{665,15}=0,09$

Rasio kekuatan nilainya lebih kecil dari 1, maka profil WF.203.203.8.12 aman digunakan.

7) Pengaku Rangka (Aksial Tarik)

$$
\begin{aligned}
& \mathrm{Pu} \leq \varnothing \mathrm{Pn} \\
& \mathrm{Pn}=\mathrm{Ag} * \mathrm{fy} \\
& \mathrm{Pn}=2724,45 \mathrm{kN} \\
& \varnothing \mathrm{Pn}=0,75 * 2724,45=2452,01 \mathrm{kN} \\
& \text { Rasio Kekuatan: } \\
& \frac{\mathrm{Pu}}{\emptyset \mathrm{Pn}}=\frac{56,84}{2452,01}=0,02
\end{aligned}
$$

Rasio kekuatan nilainya lebih kecil dari 1, maka profil WF.203.203.8.12 aman terhadap kelelehan.

$$
\begin{aligned}
& \mathrm{Pu} \leq \varnothing \mathrm{Pn} \\
& \mathrm{Pn}=\mathrm{Ae} * \mathrm{fu} \\
& \mathrm{Pn}=(\mathrm{Ag} * \mathrm{U}) * \mathrm{fu} \\
& \mathrm{Pn}=3106,54 \mathrm{kN} \\
& \varnothing \mathrm{Pn}=0,75 * 3106,54=2329,9 \mathrm{kN}
\end{aligned}
$$

Rasio Kekuatan:

$$
\frac{\mathrm{Pu}}{\emptyset \mathrm{Pn}}=\frac{56,84}{2329,9}=0,02
$$

Rasio kekuatan nilainya lebih kecil dari 1, maka profil WF.203.203.8.12 aman terhadap fraktur.

8) Pengaku Rangka (Aksial Tekan)

$$
\begin{aligned}
& \lambda \mathrm{c}=\frac{L * k}{i \min * \pi} \sqrt{\frac{f y}{E}}=1,83 \\
& \lambda \mathrm{c}>1,5 \mathrm{maka}, \\
& \mathrm{Nn}=\frac{0,88 * \mathrm{Ag} * \mathrm{fy}}{\lambda \mathrm{c}^{2}}=719,3 \mathrm{kN} \\
& \varnothing \mathrm{Nn}=0,85 * 719,3=611,36 \mathrm{kN}
\end{aligned}
$$

Rasio Kekuatan:

$$
\frac{\mathrm{Nu}}{\emptyset \mathrm{Nn}}=\frac{48,33}{611,36}=0,08
$$

Rasio kekuatan nilainya lebih kecil dari 1, maka profil WF.203.203.8.12 aman digunakan.

9) Ikatan Angin Gelagar (Aksial Tarik) 


$$
\begin{aligned}
& \mathrm{Pu} \leq \varnothing \mathrm{Pn} \\
& \mathrm{Pn}=\mathrm{Ag} * \mathrm{fy} \\
& \mathrm{Pn}=2724,45 \mathrm{kN} \\
& \varnothing \mathrm{Pn}=0,75 * 2724,45=2452,01 \mathrm{kN}
\end{aligned}
$$

Rasio Kekuatan:

$$
\frac{\mathrm{Pu}}{\emptyset \mathrm{Pn}}=\frac{177,28}{2452,01}=0,07
$$

Rasio kekuatan nilainya lebih kecil dari 1, maka profil WF.203.203.8.12 aman terhadap kelelehan.

$$
\begin{aligned}
& \mathrm{Pu} \leq \varnothing \mathrm{Pn} \\
& \mathrm{Pn}=\mathrm{Ae} * \mathrm{fu} \\
& \mathrm{Pn}=(\mathrm{Ag} * \mathrm{U}) * \mathrm{fu} \\
& \mathrm{Pn}=3106,54 \mathrm{kN} \\
& \varnothing \mathrm{Pn}=0,75 * 3106,54= \\
& \text { Rasio Kekuatan: } \\
& \frac{\mathrm{Pu}}{\emptyset \mathrm{Pn}}=\frac{177,28}{2329,9}=0,08
\end{aligned}
$$$$
\varnothing \mathrm{Pn}=0,75 * 3106,54=2329,9 \mathrm{kN}
$$

Rasio kekuatan nilainya lebih kecil dari 1, maka profil WF.203.203.8.12 aman terhadap fraktur.

\section{E. Sambungan Jembatan}

Pada desain sambungan berikut, keseluruhan baut menggunakan tipe A325 dengan tahanan putus sebesar, fub $=725 \mathrm{MPa}$. Diameter baut terdiri dari beberapa ukuran dengan maksimum diameter yaitu $\mathrm{D}=30 \mathrm{~mm}$.

\section{F. Slab Jembatan}

Jembatan Sungai Liong II ini didesain menggunakan pelat bondek sebagai bekisting pada saat pelaksanaan pekerjaan. Dengan tebal total pelat lantai yaitu $25 \mathrm{~cm}$ termasuk didalamnya tebal pelat bondek. Perhitungan momen pada slab jembatan ini dilakukan secara manual.

Total momen ultimit slab pada kombinasi 1:

Momen ultimit tumpuan $\quad \mathrm{Mu}=81,496 \mathrm{kNm}$ Momen ultimit lapangan $\quad \mathrm{Mu}=72,048 \mathrm{kNm}$ Total momen ultimit slab pada kombinasi 2:

Momen ultimit tumpuan $\quad \mathrm{Mu}=42,711 \mathrm{kNm}$ Momen ultimit lapangan $\quad \mathrm{Mu}=37,120 \mathrm{kNm}$ Pembesian slab jembatan:

Tulangan lentur negatif

Tulangan utama

D16 - 75

Tulangan susut

D13 - 100
Tulangan lentur positif
Tulangan utama
D16 - 75
Tulangan susut
D13 - 100

Lendutan ijin slab $\quad \delta_{\mathrm{ijin}}=\mathrm{Lx} / 240=7,08 \mathrm{~mm}$ Lendutan total pada plat lantai

$$
\delta \text { tot }=\delta \mathrm{e}+\delta \mathrm{g}=2,95 \mathrm{~mm}
$$

\section{G. Elastomer Jembatan}

Lebar

Panjang

Tinggi

Tebal cover atas

Tebal cover bawah

Tebal lapisan internal Jumlah lapisan

Tebal pelat baja Jumlah pelat baja

Mutu pelat baja

\section{H. Abutment Jembatan}

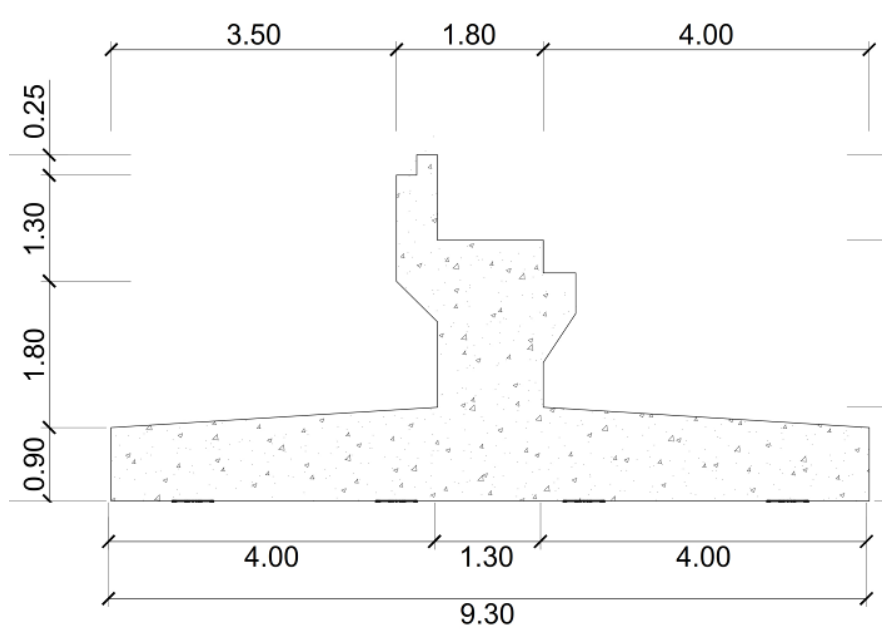

Gambar 2. Dimensi Abutment

Dimensi abutment:

\begin{tabular}{|c|c|c|c|}
\hline NOTASI & Dimensi $(\mathrm{m})$ & NOTASI & Dimensi $(\mathrm{m})$ \\
\hline $\mathrm{h}_{1}$ & 1,05 & $\mathrm{~b}_{1}$ & 0,25 \\
\hline $\mathrm{h}_{2}$ & 1,30 & $\mathrm{~b}_{2}$ & 0,25 \\
\hline $\mathrm{h}_{3}$ & 0,50 & $\mathrm{~b}_{3}$ & 1,80 \\
\hline $\mathrm{h}_{4}$ & 0,50 & $\mathrm{~b}_{4}$ & 0,50 \\
\hline $\mathrm{h}_{5}$ & 1,80 & $\mathrm{~b}_{5}$ & 1,30 \\
\hline $\mathrm{h}_{6}$ & 0,25 & $\mathrm{~b}_{6}$ & 4,00 \\
\hline $\mathrm{h}_{7}$ & 0,25 & $\mathrm{~b}_{7}$ & 4,00 \\
\hline $\mathrm{h}_{8}$ & 0,90 & $\mathrm{~b}_{8}$ & 0,40 \\
\hline
\end{tabular}




\begin{tabular}{|c|c|c|c|}
\hline $\mathrm{h}_{9}$ & 0,60 & $B_{x}$ & 9,30 \\
\hline $\mathrm{h}_{10}$ & 0,50 & & \\
\hline $\mathrm{h}_{11}$ & 0,55 & & \\
\hline
\end{tabular}

Beban pilecap:

Beban aksial $\quad \mathrm{P}=18067,19 \mathrm{kN}$

Beban horizontal arah X Tx $=15239,46 \mathrm{kN}$

Beban horizontal arah Y Ty $=1600,57 \mathrm{kN}$

Momen arah X $\quad \mathrm{Mx}=48975,05 \mathrm{kNm}$

Momen arah Y My $=5121,83 \mathrm{kNm}$

Penulangan:
Tulangan pokok
D $29-100$
Tulangan susut
D $22-100$

2) Breastwall

Beban breastwall:

Beban aksial $\quad \mathrm{P}=14601,22 \mathrm{kN}$

Beban horizontal arah X Tx $=15239,46 \mathrm{kN}$

Beban horizontal arah Y Ty $=1600,57 \mathrm{kN}$

Momen arah X $\quad \mathrm{Mx}=31638,44 \mathrm{kNm}$

Momen arah Y My $=3281,17 \mathrm{kNm}$

Penulangan:

Tulangan tekan

2D $22-100$

Tulangan tarik

2D $22-100$

3) Corbel

Beban corbel:

Beban aksial

Gaya geser

Momen ultimit

Penulangan:

Tulangan pokok

Tulangan susut

$$
\begin{aligned}
\mathrm{P} & =13189,99 \mathrm{kN} \\
\mathrm{Vu} & =13189,99 \mathrm{kN} \\
\mathrm{Mu} & =2638,00 \mathrm{kNm}
\end{aligned}
$$

D $16-200$

D $13-300$

\section{Tiang Pancang Jembatan}

Tiang pancang yang digunakan berupa tiang Spun Pile dengan diameter $50 \mathrm{~cm}$ dan panjang $20 \mathrm{~m}$. Abutment ditanam kedalam tanah sedalam $80 \mathrm{~cm}$ sehingga tidak terdapat tanah asli yang membebani pile cap abutment. Perhitungan kapasitas dukung tiang pancang mengggunakan metode Schmertmann dengan safety factor yaitu 3 .

$\mathrm{Cn} 1=11,05 \mathrm{~kg} / \mathrm{cm}^{2}$

$\mathrm{Cn} 2=10,43 \mathrm{~kg} / \mathrm{cm}^{2}$

$\mathrm{Cn} 3=8,26 \mathrm{~kg} / \mathrm{cm}^{2}$

Cn3 min rata-rata $=7,67 \mathrm{~kg} / \mathrm{cm}^{2}$

$\mathrm{Cn}$ rata-rata $=$

$((1 / 2 *(\mathrm{Cn} 1+\mathrm{Cn} 2))+\mathrm{Cn} 3)=9,20 \mathrm{~kg} / \mathrm{cm}^{2}$
Tahanan ujung tiang

$\mathrm{Qb}=\mathrm{Cn}$ rata-rata $\mathrm{x} \mathrm{A}=18068 \mathrm{~kg}$

$\mathrm{Qb}=18,07$ ton

Tahanan selimut tiang

Qs $=\Sigma 1+\Sigma 2=345,52$ ton

Tahanan ultimit 1 tiang

$\mathrm{Q}$ ult 1 tiang $=\mathrm{Qs}+\mathrm{Qb}=363,59$ ton

Jumlah baris $\mathrm{m}=4 \mathrm{bh}$

Jumlah tiang tiap 1 baris $\mathrm{n}=7$ bh

Total jumlah tiang $\quad \mathrm{N}=28 \mathrm{bh}$

Efisiensi group

$\operatorname{Eg}=1-((\theta *(n-1) * m+(m-1) * n) / 90 * m * n)=0,671$

Daya dukung tiang group

$\mathrm{Q}$ ult group $=\mathrm{N}^{*} \mathrm{Eg}^{*} \mathrm{Q}$ ult 1 tiang $=6829,18$ ton

Beban total

$\mathrm{W}_{\text {total }}=\mathrm{Ws}+\mathrm{W}_{\text {tiang }}$

Faktor keamanan

$=1969,12$ ton

Cek faktor keamanan

$\mathrm{SF}=\mathrm{Q}$ ult group $/ \mathrm{W}$ total $\quad=3,47>\mathrm{SF}$ ijin

Setelah dilakukan perhitungan daya dukung kelompok tiang pancang didapati faktor keamanan lebih besar dari nilai SF ijin sehingga jumlah tiang pancang yang direncanakan aman memikul beban.

\section{J. Lendutan Jembatan}

Lendutan ijin jembatan $\mathrm{L} / 240=0,4583 \mathrm{~m}$ $\mathrm{L} / 240=458,33 \mathrm{~mm}$

Tabel III

Lendutan Total Jembatan

\begin{tabular}{|l|c|c|}
\hline \multicolumn{1}{|c|}{ Kombinasi Beban } & Lendutan $(\mathrm{mm})$ & Ket. \\
\hline Kombinasi 1 & 119,88 & OK \\
\hline Kombinasi 2 & 99,07 & OK \\
\hline Kombinasi 3 & 98,15 & OK \\
\hline Kombinasi 4 & 75,00 & OK \\
\hline
\end{tabular}

K. Stud Connector

Gaya geser maksimum rencana $\mathrm{V} \max =86,64 \mathrm{kN}$ Stud connector dari tumpuan ke 1/4L: 2D12-100 Stud connector dari 1/8L sampai 1/2L: 2D12-200

\section{Metode Pelaksanaan}

Dalam pelaksanaan pembangunan jembatan Sungai Liong II ini digunakan metode Temporary Coloumns, hal ini dikarenakan tidak 
memungkinkan menggunakan metode perancah. Batang tarik vertikal tidak didesain menahan gaya tekan berat struktur rangka. Adapun tahapan pelaksanaan pembangunan jembatan busur baja dengan metode temporary coloumns sebagai berikut:

1. Tahap awal pembangunan yaitu dengan pembuatan abutment sebagai perletakan jembatan. Abutment bertumpu pada tiang-tiang pancang yang terbuat dari material beton prategang.

2. Setelah pembangunan abutment selesai, dilakukan pemasangan kolom/tiang sementara yang terbuat dari rangka baja. Kolom ini diangkurkan pada abutment agar tidak tumbang atau bergeser.

3. Selanjutnya dilakukan pembuatan anchor sebagai penahan kabel baja. Anchor ini dibangun dibawah muka tanah agar dapat menahan tarikan dari kabel baja dan bersifat sementara selama proses pembangunan jembatan busur baja.

4. Setelah kolom sementara dan anchor selesai dibangunan, tahap selanjutnya yaitu pemasangan struktur rangka baja pelengkung. Diawali dengan pemasangan bottom chord, dilanjutkan dengan diagonal chord dan dikunci dengan top chord. Tiap-tiap sambungan menggunakan menggunakan pelat buhul dan dibaut.

5. Untuk mempertahankan posisi struktur rangka agar tidak guling akibat perletakan hanya disalah satu sisi atau kantilever, maka dilakukan pemasangan kabel baja yang mengikat pada top chord kemudian di hubungkan ke ujung kolom sementara dan diangkurkan ke anchor.

6. Pekerjaan dilanjutkan dengan pemasangan segmen-segmen rangka baja berikutnya. Dan pada setiap selesai 3 segmen rangka, dilakukan pemasangan kabel baja sebgai penahan.

7. Setelah semua struktur rangka pelengkung baja terpasang dan terkunci. Tahapan selanjutnya yaitu pemasangan batang tarik vertikal yang menghubungkan gelagar dengan struktur rangka baja pelngkung.

8. Pemasangan batang tarik dimulai dari pangkal jembatan yang kemudian dikunci dengan gelagar memanjang dan gelagar melintang jembatan.
Pekerjaan dilanjutkan hingga seluruh batang tarik dan gelagar jembatan terpasang

9. Tahap selanjutnya yaitu pemasangan pelat dek sebagai perancah pengecoran slab jembatan. Kemudian dilakukan pengecoran slab jembatan serta trotoar dan pemasangan railing jembatan.

10. Setelah struktur atas selesai dibangun, kabel baja penahan struktur pelengkung dilepas dan kolom sementara dibongkar kembali. Sehingga beban gelagar bertumpu pada struktur rangka baja pelengkung.

\section{Gambar Rencana}

Berikut gambar rencana hasil perhitungan struktur atas dan bawah jembatan.

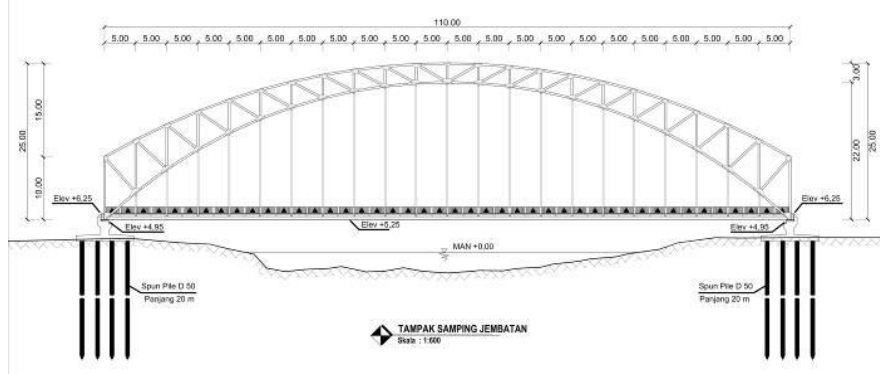

Gambar 3. Tampak Samping Jembatan

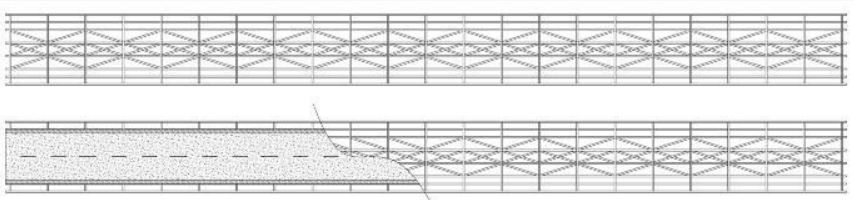

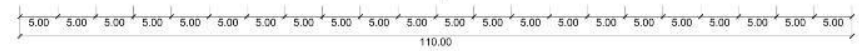

Gambar 4. Tampak Atas Gelagar

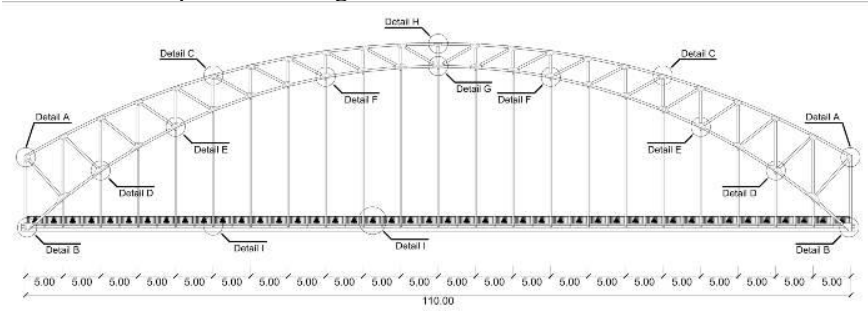

Gambar 5. Sambungan Rangka Jembatan 

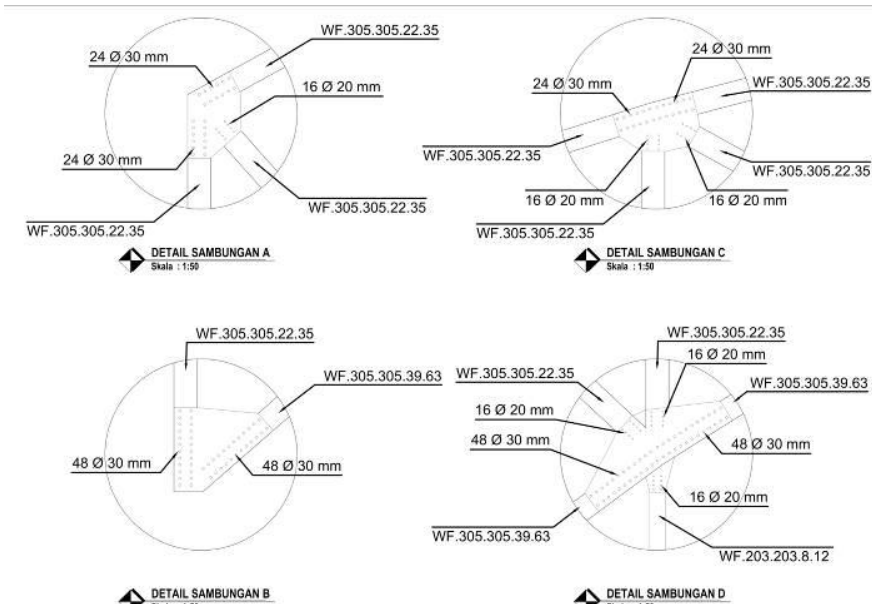

$\triangle$ DETALI SAMUUNGAN B

$\triangle$ DEFAL S SMBUUNGAND

Gambar 6. Detail Sambungan 1

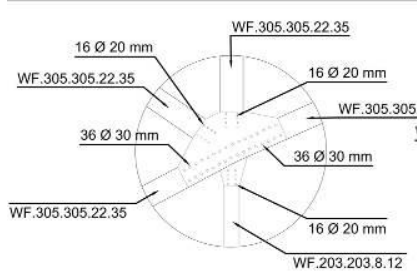

$\triangle$ DEFAL SSMBUUNGANE

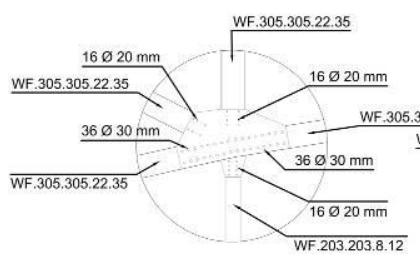

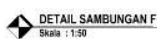

Gambar 7. Detail Sambungan 2
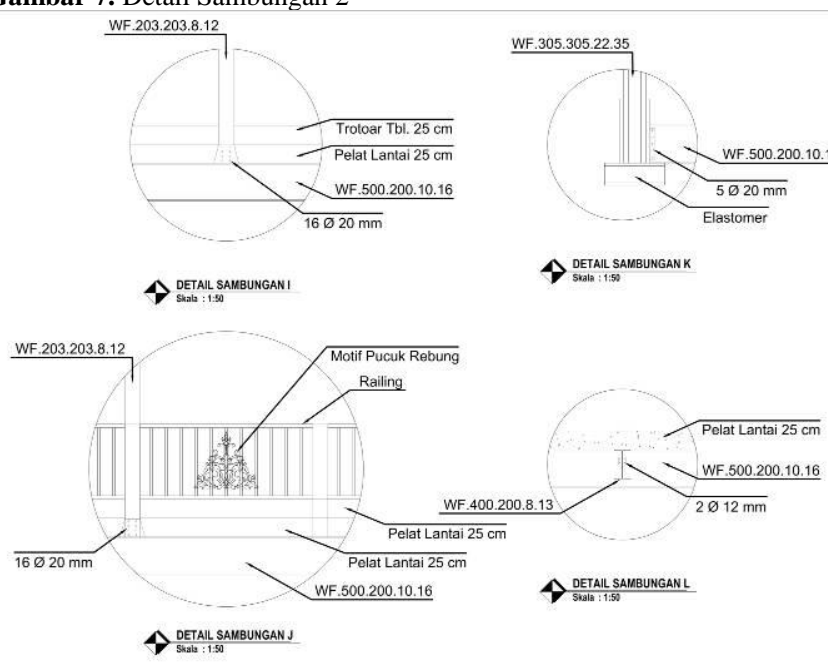

Gambar 8. Detail Sambungan 3

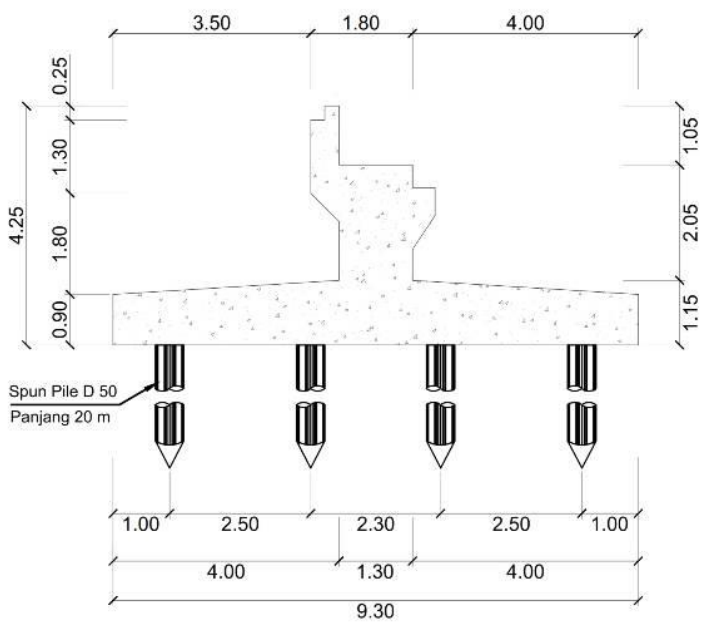

Gambar 9. Tampak Samping Abutment

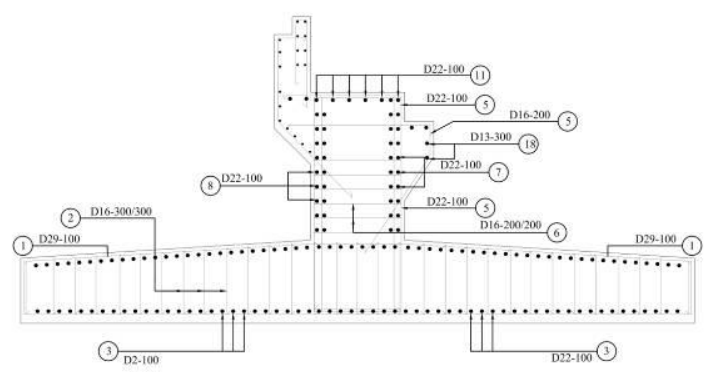

Gambar 10. Penulangan Abutment
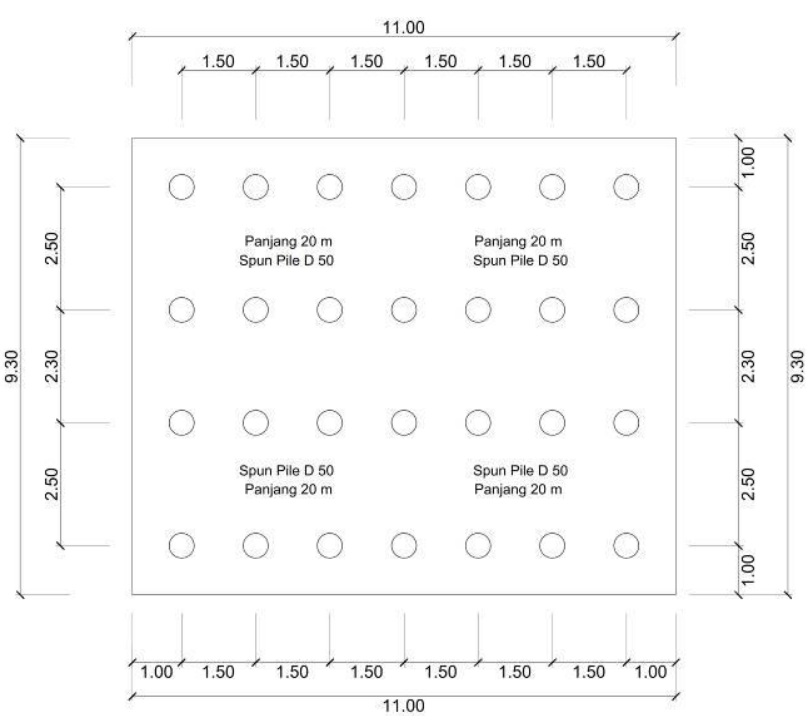

Gambar 11. Titik Pemancangan Abutment 


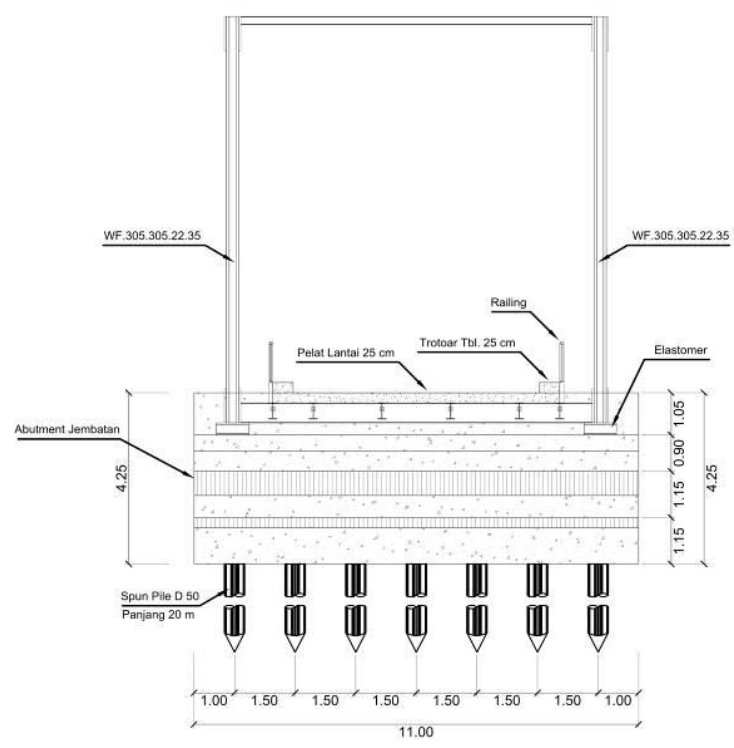

Gambar 12. Potongan 1 Jembatan

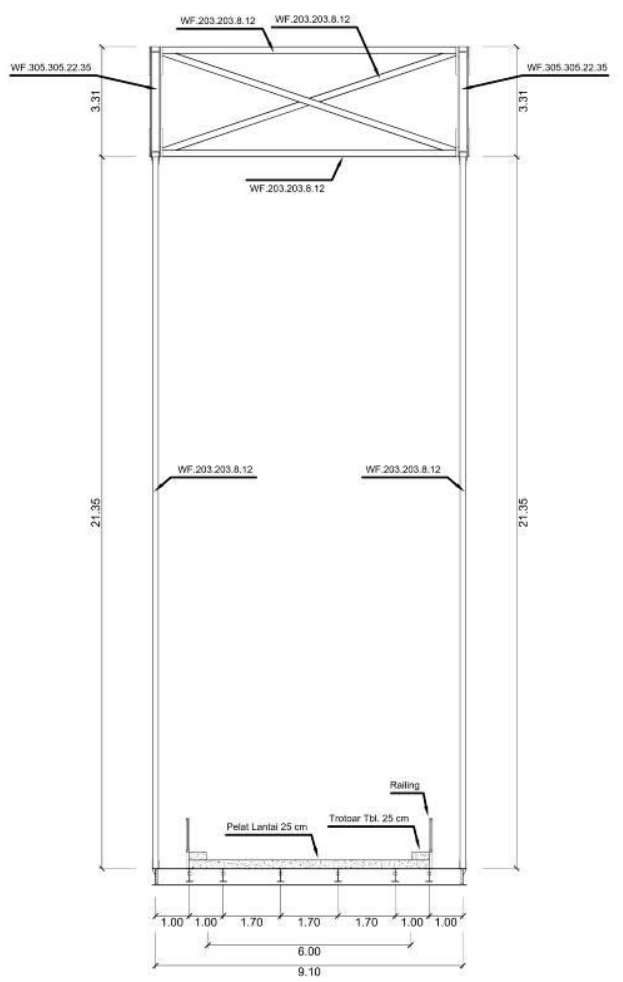

Gambar 13. Potongan 2 Jembatan

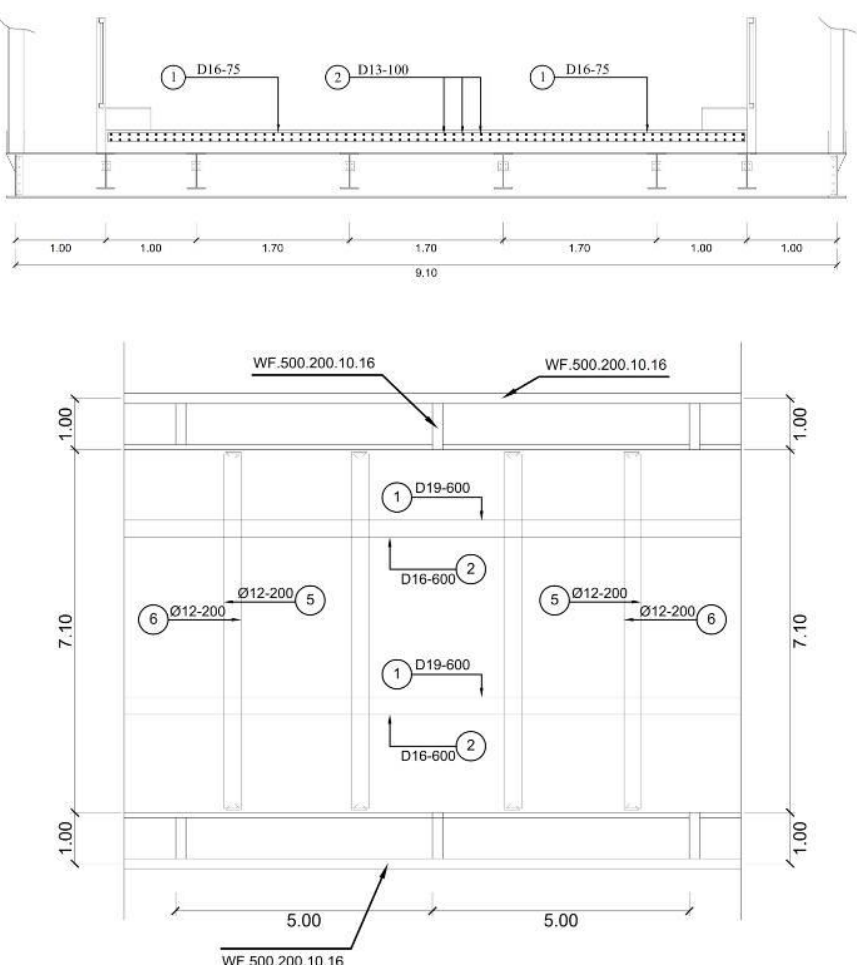

Gambar 14. Penulangan Pelat Lantai

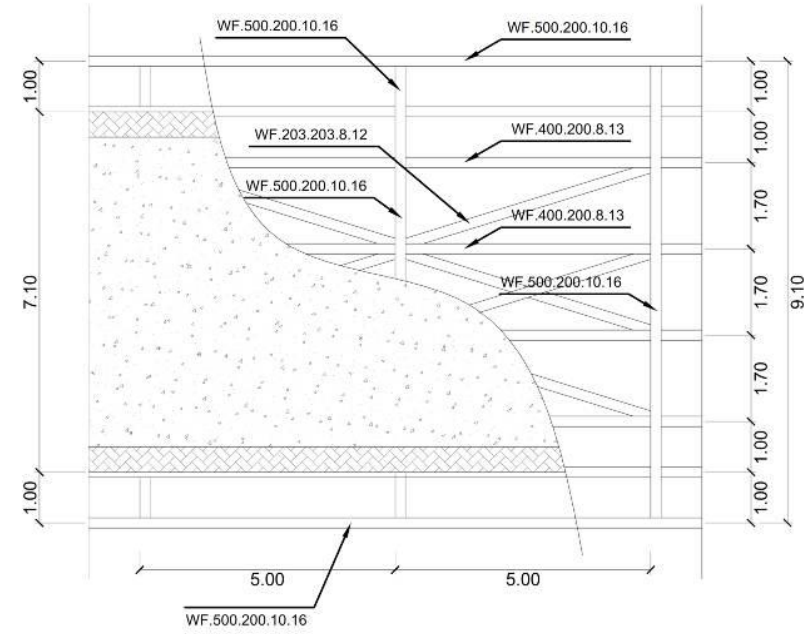

Gambar 15. Pelat Lantai dan Gelagar Jembatan

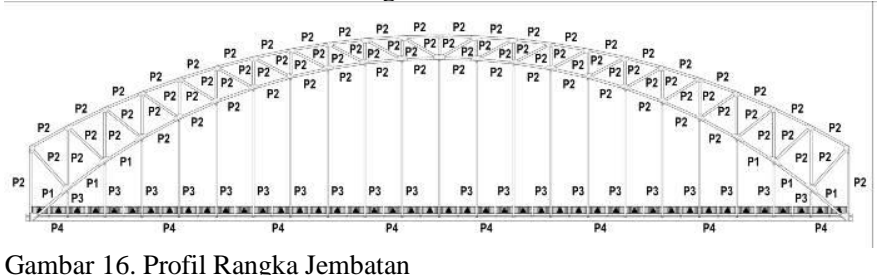

Gambar 16. Profil Rangka Jembatan 


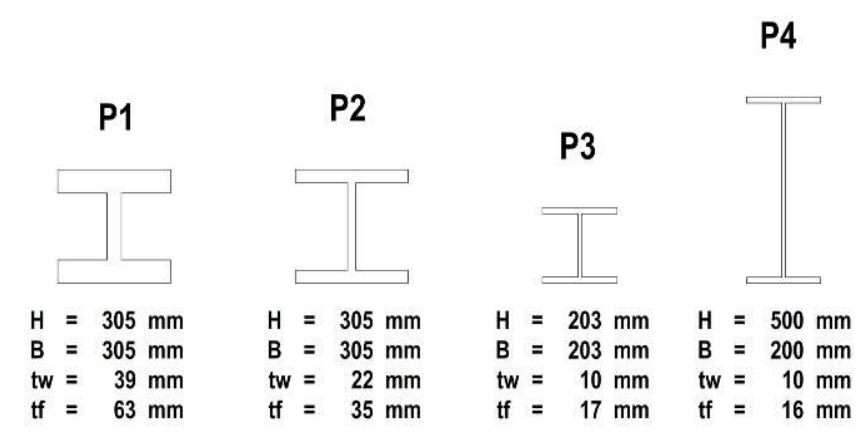

Gambar 17. Dimensi Profil

\section{KESIMPULAN}

Kesimpulan dari hasil perencanaan ini yaitu didapati profil rangka baja yang aman memikul beban baik aksial, geser serta momen hasil analisis pemebebanan. Juga didapati hasil perencanaan struktur bawah berupa abutment dan tiang pancang jembatan. Lendutan yang terjadi masih aman karena masih jauh dari lendutan yang diijinkan. Untuk metode pelaksanaan yang paling tepat untuk pembangunan jembatan Sungai Liong II ini adalah metode Temporary Coloumns.

\section{UCAPAN TERIMA KASIH}

Terimakasih diucapkan kepada rekan-rekan yang turut serta membantu dalam menyelesaikan perencanaan jembatan ini baik secara moral maupun materil. Mudah-mudahan dapat memberikan manfaat lebih dan dapat menjadi rujukan dalam perencaan jembatan rangka baja pelengkung.

\section{REFERENSI}

07/SE/M/2015, Surat Edaran Menteri Pekerjaan Umum dan Perumahan Rakyat Nomor 07/SE/M/2015, Pedoman Persyaratan Umum Perencanaan Jembatan, Jakarta.

Chen, W.F., Duan, L., 2015, Construction and Maintenance Bridge Engineering Handbook Second Edition, CRC Press, New York.

RSNI T-02-2005, Pembebanan Untuk Jembatan, Badan Standardisasi Nasional, Jakarta.

RSNI T-03-2005, Perencanaan Struktur Baja Untuk Jembatan, Badan Standardisasi Nasional, Jakarta.
RSNI T-12-2004, Perencanaan Struktur Beton Untuk Jembatan, Badan Standardisasi Nasional, Jakarta.

Struyk, J.H., Van Der Veen, W.C.H.K., 1984, alih bahasa Soemargono, Jembatan, Penerbit Pradnya Paramita, Jakarta.

Supryadi,B., Muntohar A.S., 2007, Jembatan, Beta Offset, Yogyakarta.

Vaza,H.,dkk., 2010, Perencanaan Teknik Jembatan, Kementrian Pekerjaan Umum Direktorat Jendral Bina Marga Direktorat Bina Teknik, Jakarta.

Wikibooks.org. Rekayasa Lalu Lintas. Dipetik 18 Januari 2018. https://id.wikibooks.org/wiki/ Rekayasa_Lalu_Lintas/Jembatan.

Wikipedia.org. Jembatan. Dipetik 18 Januari 2018. https://id.wikipedia.org/wiki/Jembatan. 